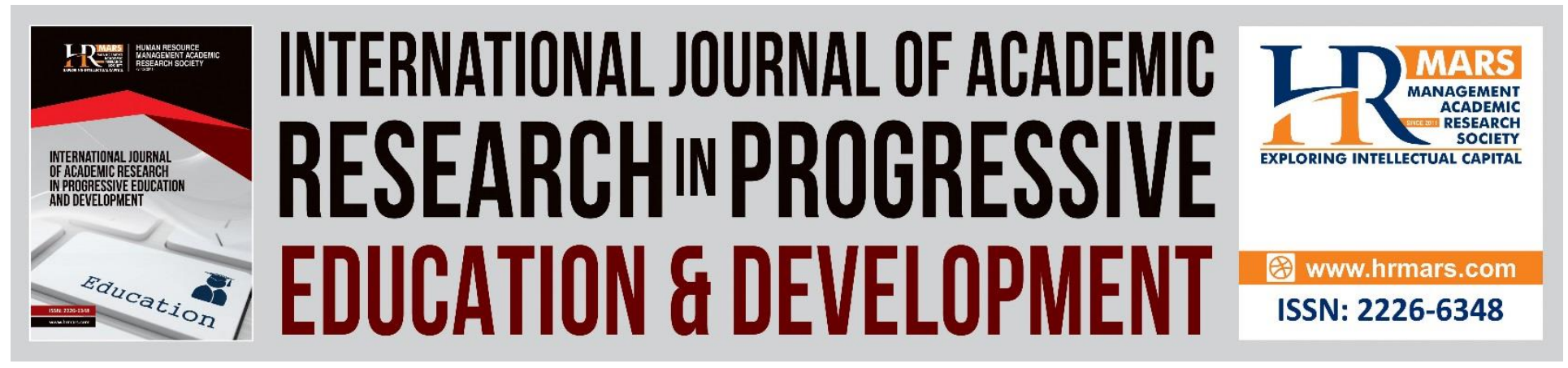

\title{
Formal Instruction and Its Effects on the Acquisition of English Affricate Consonants
}

\author{
Sukardi Weda, Andi Elsa Fadhilah Sakti
}

To Link this Article: http://dx.doi.org/10.6007/IJARPED/v7-i3/4208

DOI: $10.6007 /$ IJARPED/v7-i3/4208

Received: 25 April 2018, Revised: 29 May 2018, Accepted: 17 June 2018

Published Online: 21 June 2018

In-Text Citation: (Weda \& Sakti, 2018)

To Cite this Article: Weda, S., \& Sakti, A. E. F. (2018). Formal Instruction and Its Effects on the Acquisition of English Affricate Consonants. International Journal of Academic Research in Progressive Education and Development, 7(3), 1-13.

\section{Copyright: (c) 2018 The Author(s)}

Published by Human Resource Management Academic Research Society (www.hrmars.com)

This article is published under the Creative Commons Attribution (CC BY 4.0) license. Anyone may reproduce, distribute, translate and create derivative works of this article (for both commercial and non-commercial purposes), subject to full attribution to the original publication and authors. The full terms of this license may be seen at: http://creativecommons.org/licences/by/4.0/legalcode

Vol. 7, No. 3, July 2018, Pg. 1 - 13

http://hrmars.com/index.php/pages/detail/IJARPED

JOURNAL HOMEPAGE

Full Terms \& Conditions of access and use can be found at http://hrmars.com/index.php/pages/detail/publication-ethics 


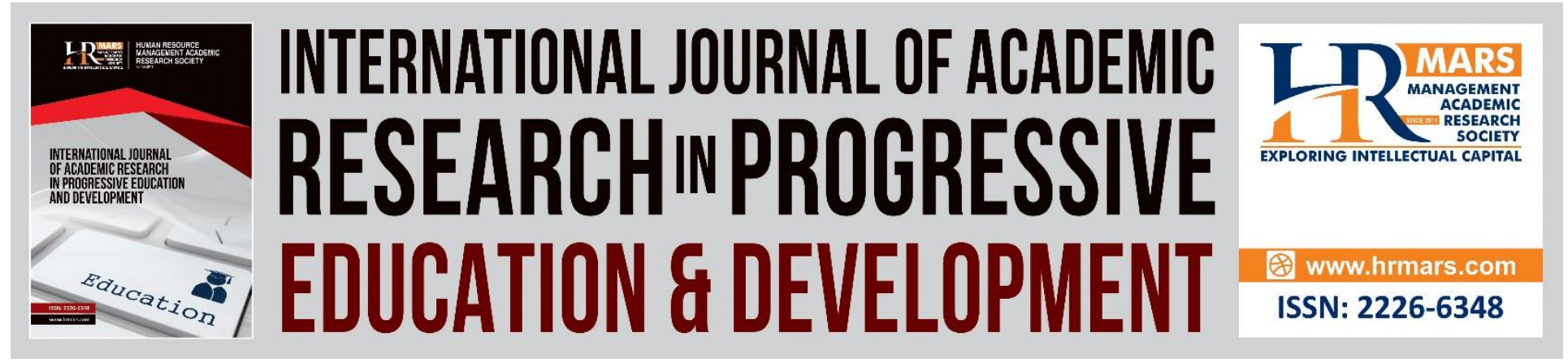

\title{
Formal Instruction and Its Effects on the Acquisition of English Affricate Consonants
}

\author{
Sukardi Weda \\ Universitas Negeri Makassar \\ Email: sukardi.weda@unm.ac.id \\ Andi Elsa Fadhilah Sakti \\ Universitas Negeri Makassar \\ Email: andielsafadhilahs@yahoo.co.id
}

\begin{abstract}
Indonesian and English have some differences dealing with their symbols or phonemes in the points and manner of articulation. On the other hand, they have the same symbols and phonemes in affricate consonants, voiceless alveolar-palatal / $t /$ and voiced alveolar-palatal / $\mathrm{d} 3 /$. This study therefore aims to find out whether formal instruction improve the acquisition of English fricative consonants by Indonesian learners of English. The study employed quasi experimental design, the nonequivalent control group design. It used two groups, one received treatment (formal instruction) and another group was taught conventionally. The population of this study is students of English Literature Study Program Faculty of Languges and Literature Universitas Negeri Makassar Indonesia. There were 64 students participated as subjects of this study. The subjects ranging from $17-19$ years old attended an English phonology subject in 2016/2017 academic year. The study reveals that formal instruction improves the acquisition of English affricate consonants by Indonesian learners of English. There are two main conclusions of this study. The first one is that the Indonesian learners of English met difficulties in transcribing English affricate consonants $[t]$ and $\left[d_{3}\right]$ in pretest, either for control group or experimental group. The second main finding as the primary concern of this study is that the formal instruction improved students' acquisition of English affricate consonants [t]] and [dz], where the subjects' answers toward the list of words significantly improved.
\end{abstract}

Key words: Formal Instruction, Affricate Consonants, English, Tertiary Level

\section{Introduction}

English is an international language and becomes instructional language in science and technology distribution. It therefore becomes language for knowledge sharing in international arena. To be competent in English, is not an easy job. This is because English presents many difficulties with regard to its skills and elements. One of those elements is the pronunciation. 


\section{INTERNATIONAL JOURNAL OF ACADEMIC RESEARCH IN PROGRESSIVE EDUCATION AND}

DEVELOPMENT

Vol. 7, No. 3, July 2018, E-ISSN: 2226-6348 @ 2018 HRMARS

English has different spelling and its pronunciation. This phenomenon becomes primary problem for learners of other language speakers, including the speakers of bahasa Indonesia. English and Indonesian have voiceless alveolar-palatal $/ \mathrm{t} /$ and voiced alveolar-palatal / $\mathrm{d} /$. The primary problems made by Indonesian speakers or learners of English are they felt difficulties in trancribing and pronouncing those symbols or segmental phonemes. The difference in phonetic classification and symbol overlooks subsegmental difference in aspiration that exists between the two. In English there are many sounds symbolized by palato-alveolar $/ \mathrm{t} / /$ and $/ \mathrm{d} 3 /$. These sounds make difficulties to Indonesian speakers of English.

It is argued that the pronunciation problems encountered by Indonesian learners of English occur because the way of pronouncing English and Indonesian language is different. Roach (1987) says that one of the things that everybody knows about language is that they have different accents. He adds that langauges are pronounced differently by people from different geographical places, from different social classes, of different ages, and different education background and absolutely from different culture. As an international language, English presents some varieties in terms of its pronunciation used by people from various regions. So that, the learners of English needs to know the correct accents and pronunciations used by the speakers of standard English in other they can maintain good communication to others. If not, they cannot express and understand utterances from others. Gilakjani (2011) argues that pronunciation is one of the most intriguing skills in English language teaching at the classroom setting. He therefore adds that if the speakers have bad pronunciation, their speech will not be understood by other people and potentially causes misunderstanding.

Advanced foreign language (FL) learners' difficulties in conveying their message to native speakers may, however, relate less to their vocabulary, grammatical, or phonological errors than to their way of structuring oral discourse in all levels of communication (Maeno, 1995). Maeno therefore says that producing culturally appropriate extened discourse units is perhapas the most challenging aspect of foreign language (FL) acquisition and language learning.

The difference in pronunciation makes second language (L2) or foreign language (FL) leaners difficult to speak the L2 or FL. The language leaners also consume lots of time in the early process of language learning because they need some adjuctments. Their native language pronunciation is different with second language (L2) or foreign language (FL), therefore they employ their native language pronunciation in the target language which so called interference. Hassan (2014) concludes in his study that factors such as interference, the differences in the sound system in the two languages, inconsistency of English sounds and spelling militate against Sudanese students of English competence in pronunciation.

The difficulties of understanding language elements in English cause some English learners demotivate to learn English as a foreign language (EFL) in Indonesia. One of the causes of the students' low interest and motivation to learn English is its elements (grammar, vocabulary, and pronunciation. So that serious attention on pronunciation needs to employ in the learning and teaching process in the English as a foreign language (EFL) classroom. In keeping with this, Chan and $\mathrm{Li}$ (2000) argue that pronunciation errors which affect intelligibility or create communication problems should be given priority in remedial teaching in all levels of teaching English as a foreign language (EFL) or English as a second language (L2).

To improve students' pronunciation, there are lots of methods, approaches, strategies employed by the teachers in the classroom setting. One of those methods is formal instruction. 
Vol. 7, No. 3, July 2018, E-ISSN: 2226-6348 @ 2018 HRMARS

Formal instruction has been employed by some researchers in their study which shows the positive effect on pronunciation (Elliot, 1995 and González-Bueno, 1997).

Based on the issues as previously stated, this present study confines its investigation to the acquisition of affricate consonants of the English literature study program Faculty of Languages and Literature Universitas Negeri Makassar, Indonesia. It is in relation with the English phonology and pronunciation, segmental phoneme in particular, affricate consonants $/ \mathrm{t} /$ and /dz/ are interesting phenomenon in language learning made by interlanguage speakers. Hence, this present study is not concerned with such issues as error analysis.

Therefore, the key research question underlying this study is "Does formal instruction improve students' acquisition of affricate consonants at the English literature study program, Universitas Negeri Makassar, Indonesia?.

\section{Review of Literature}

\subsection{Previous studies}

Some studies have been conducted by researchers in any languages using formal instruction. Elliot (1995) reported in his study that neither foreign language (FL), nor subject concern for pronunciation accuracy, were significant predicators of improvements in pronunciation under formal instruction.

Mora and Fullana (2007) revealed in their study that neither starting age nor experience had a significant effect on how accurately participants perceived and produced the two vowel contrasts, although a late starting age advantage was observed as suggested by previous research conducted in formal instuction settings.

Elliot (1997) found that his study imply a need for formal phonological instruction at the intermediate level. He added that the findings suggest that teaching pronunciation to adults is beneficial in the acquisition of Spanish pronunciation as evidence by the experimental group subjects' overall improvement in pronunciation over the course of the semester.

Bui (2016) showed that the EFL learners' problems in pronouncing / $\theta /$ and $/ \delta /$ need attention from the teachers. Along with giving proper instruction, the teachers can acknowledge the students about the possible mistakes they might make. Moreover, it is significant to create an environment in which the students can feel confident and motivated to make use of their English on a regular basis. These studies show the benefits of the inclusion of formal instruction in improving learners' pronunciation in L2 classroom. Similarly, this study examines whether the formal instruction can improve students' pronunciation in fricative consonants.

González-Bueno (1997) demonstrates that afer receiving formal instruction in the pronunciation of Spanish stops, subjects of the experimental group produced Spanish stops with VOT duration at the post test were shorter than the VOT duration of stops produced at the pretest. He adds that formal instruction can account for the improvement in the pronunciation of only these two sounds, /p/ and /g/. However, it would appear that the trend towards improvement in the pronunciation of the remaining stops $/ b, t, d, k /$ by the experimental subjects is also due to formal instruction in the pronunciation of these Spanish sounds. The conclusion of González-Bueno's studies is that the experiment seem to be an indication of some positive effect that formal instruction has on the improvement of the pronunciation of Spanish stops. 
INTERNATIONAL JOURNAL OF ACADEMIC RESEARCH IN PROGRESSIVE EDUCATION AND DEVELOPMENT

Vol. 7, No. 3, July 2018, E-ISSN: 2226-6348 @ 2018 HRMARS

2.2 English and Indonesian consonants sounds

English and Indonesian consonant sounds can be classified according to their manner of articulation and their place of articulation. There are 20 consonants in Indonesian as revealed in table 1 and there are 24 consonants in English as illustrated in table 2.

2.2.1 Indonesian consonants sounds

Table 1. Indonesian consonant sounds (Soderbeg, 2008)

\begin{tabular}{|c|c|c|c|c|c|c|c|c|}
\hline & Bilabial & $\begin{array}{l}\text { Labio- } \\
\text { dental }\end{array}$ & Dental & Alveolar & $\begin{array}{l}\text { Post- } \\
\text { alveolar }\end{array}$ & Palatal & Velar & Glottal \\
\hline $\begin{array}{l}\text { Plosive \& } \\
\text { affricate }\end{array}$ & $p b$ & & t & $d$ & $t d d_{3}$ & & $\mathrm{~kg}$ & (') \\
\hline Nasal & $\mathrm{m}$ & & & $\mathrm{n}$ & & $\mathrm{n}$ & $\eta$ & \\
\hline Flap/trill & & & & $r$ & & & & \\
\hline Fricative & & (f) & & $s \quad(z)$ & (J) & & & \\
\hline Approximant & $w$ & & & & & j & & \\
\hline $\begin{array}{l}\text { Lateral } \\
\text { approximant }\end{array}$ & & & & I & & & & \\
\hline
\end{tabular}

2.2.2 English consonant sounds

Table 2. Chart of English consonant phonemes (Roach, 1987), (Díaz-Campos, 2004) Bilabial Labiodent Dental Alveola Palato- Palatal Velar Glottal al $\quad r$ alveola

\begin{tabular}{|c|c|c|c|c|c|c|c|c|c|c|c|c|c|c|c|}
\hline & \multicolumn{15}{|c|}{$r$} \\
\hline & - & + & - & + & - & + & - & + & - & + & - & + & - & + & $-\quad+$ \\
\hline Plosive & $p b$ & & & & & & $\mathrm{td}$ & & & & & & $\mathrm{kg}$ & & \\
\hline Fricative & & & $f v$ & & $\theta \delta$ & & S Z & & $\int 3$ & & & & & & $\mathrm{~h}$ \\
\hline Affricate & & & & & & & & & $t d$ & & & & & & \\
\hline Nasal & $\mathrm{m}$ & & & & & & $n$ & & & & & & $\eta$ & & \\
\hline Lateral & & & & & & & 1 & & & & & & $t$ & & \\
\hline Flap & & & & & & & & & $r$ & & & & & & \\
\hline $\begin{array}{l}\text { Approxima } \\
\text { nt }\end{array}$ & & & & & & & & & $1 d$ & & & & & & \\
\hline Glide & $w$ & & & & & & & & & & j & & & & \\
\hline
\end{tabular}

\subsection{The affricates of English}

The affricate consonants in English can be seen in the table 3 below:

Table 3. The affricate consonants of English

\begin{tabular}{lc}
\hline & Palato-alveolar \\
\hline $\begin{array}{l}\text { Fortis } \\
\text { (Voiceless) }\end{array}$ & $\mathrm{t}$ \\
\hline Lenis & $\mathrm{d}$ \\
(Voiced) & \\
\hline
\end{tabular}


Vol. 7, No. 3, July 2018, E-ISSN: 2226-6348 @ 2018 HRMARS

\subsubsection{Affricate Consonants}

Affricates $[t]$ and $\left[d_{3}\right]$ are produced by a stop closure followed immediately by a gradual release of the closure that produces an effect characteristic of a fricative (Fromkin and Rodman, 2007). They therefore argue that the palatal sounds that begin and end the words church and judge are voiceless and voice affricates, respectively. $\mathrm{t} \int$ and $\mathrm{d}_{3}$ are the only two affricate phonemes in English and the voicing characteristics are the same as for plosives and most of the fricatives (Roach, 1987). Roach adds that the place of articulation is the same as for $\int$ and 3, that is, palatoalveolar. This means that the $\mathrm{t}$ component of $\mathrm{t} \int \mathrm{has}$ a place of articulation rather further back in the mouth than the $t$ plosive usualy has.

Gimson (1985) gives examples and description of palato-alveolar affricates as follows:

\section{(1)Examples}

$/ \mathrm{t}$ /- fortis (spelt ch, tch, $t+$ ure, eous, and $t+i o n$ when $t$ is preceeded by $\mathrm{s}, \mathrm{e.g}$. 'chain, watch, nature, righteous, question')

word initial-cheese, chin, charge, churn, choke, cheer

word media (intervocalic)-feature, richer, wretched, orchard, butcher, nature, merchant

(consonant preceding)- gesture, posture, mischief, juncture, cupture, lecture, pilchard, culture, adventure

word final-wretch, catch, larch, porch, much, coach

(consonant preceding)-inch, conch, bench, branch, filch, mulch

/dz/-lenis (spelt $j, g, d g$, sometimes $g g, d j$, de, di, ch, e.g. 'jam, gem, midget, suggest, adjacent, grandeur, soldier, Norwich')

word initial-gin, jest, jar, jaunt, Jew, jerk, joke, joist, jeer

word medial (intervocalic)-midget, ledger, margin, fragile, urgent, orgy, adjacent, agenda, major

(consonant preceding)- avenger, danger, stringent, soldier, Belgian, bulges, object

word final-ridge, edge, large, dodge, judge, huge, age, doge, gouge

(consonant preceding)-bilge, bulge, hinge, sponge, change

Compare /t $\mathrm{J} /, / \mathrm{d}_{3} /$-chin, gin; chest, jest; choose, Jews: choke, joke; cheer, jeer; catcher, cadges; nature, major; a venture, avenger; richer, ridges; leech, liege; larch, large; perch, purge; lunch, lunge; cinch, singe; beseech, besiege

(2)Description. - The soft palate being raised and the nasal resonator shut off, the obstacle to the air-stream is formed by a closure made between the tip, blade, and rims of the tongoue and the upper alveolar ridge and side teeth. At the same time, the front of the tongue is raised towards the hard palate in readiness for the fricative release.

\section{Research Method}

\subsection{Experimental Design and Methodology}

This peresent study employed quasi-experimental design, the non-equivalent control group design. It used two groups, one received treatment (formal instruction) with systematic ways and another group was taught conventionally with little exercises and practices. The hypothesis that the current study tests is: Formal instruction enhances students' acquisition of English pronunciation in voiceless alveolar-palatal $/ t /$ and voiced alveolar-palatal $/ d z /$. The experimental group was the class B of the English Phonology class and the control group was the Class A of the English Phonology subject. The data in this study were obtained from the first semester students 
Vol. 7, No. 3, July 2018, E-ISSN: 2226-6348 @ 2018 HRMARS

of English Literature study program Faculty of Languages and Literature Universitas Negeri Makassar, Indonesia who attended English Phonology subject in 2016/2017 academic year. There were 64 students who participated as subjects of this study. The subjects ranging from $17-19$ years old. The demographic characteristics of the students is illustrated in Table 4.

Table 4. Demographic characteristics of the students

\begin{tabular}{lcc}
\hline $\begin{array}{c}\text { Demographic } \\
\text { characteristics }\end{array}$ & $\mathrm{n}$ & $\%$ \\
\hline Age & 64 & 100 \\
$17-19$ & & \\
\hline Gender & & \\
Male & 17 & 25.56 \\
Female & 47 & 73.48 \\
\hline
\end{tabular}

\subsection{Variables of the Study}

There were two variables in this study, independent variable and dependent variable. Formal instruction as independent variable and students' acquisistion of affricate consonants as dependent variable of the study.

\subsection{The Test}

There were two test employed in this current study, the pre-test and post-test. The pre-test was administered at the beginning of the study to find out preliminary data and the post-test was administered at the end of the study. There was treatment given to the experimental group between pre-test and post-test. The treatment is "formal instruction" in which the instructional pattern was given dealing with the theoretical and practical introduction of affricate consonant sounds in English (voiceless alveolar-palatal / $t /$ and voiced alveolar-palatal /ds/).

\subsection{Procedure of Data Collection}

The data were collected using a written test. The data obtained from the written test were checked and analyzed to enable the researchers to identify the correct and incorrect pronunciation of English affricate consonants made by the students. The significant source for actual English affricate transcription was Oxford Advanced Learner's Dictionary of Current English by Hornby (1987).

\subsection{The Data Analysis}

The pre-test and post-test of experimental group and control group were analyzed using Statistical Package for Social Sciences (SPSS) IBM SPSS Statistics 20 showing the t-test, mean, standard deviation (SD), percentage, and histogram.

\section{Findings and Discussion}

Test of significance (t-test) was employed to test the hypothesis. This test was used to identify the significant difference between the results of students' mean score of the students who taught 
INTERNATIONAL JOURNAL OF ACADEMIC RESEARCH IN PROGRESSIVE EDUCATION AND DEVELOPMENT

Vol. 7, No. 3, July 2018, E-ISSN: 2226-6348 @ 2018 HRMARS

the subject using formal instruction and the students who taught the subject using conventional way.

| Table 5. The frequency and percentage of students' answers in pretest for control group

\section{Control}

\begin{tabular}{lrrrrr}
\hline Students' Answers & & Frequency & Percent & $\begin{array}{c}\text { Valid } \\
\text { Percent }\end{array}$ & Cumulative Percent \\
\hline \multirow{4}{*}{ Valid } & .00 & 30 & 93.8 & 93.8 & 93.8 \\
& 1.00 & 1 & 3.1 & 3.1 & 96.9 \\
& 4.00 & 1 & 3.1 & 3.1 & 100.0 \\
\hline
\end{tabular}

As shown in table 5 that from 32 subjects, there were only 1 or $3.1 \%$ of the students gave one correct transcription to the list of word to identify the transciption of affricate consonants in the word. There were only 1 or $3.1 \%$ of the students gave four correnct transciptions to the list of words. In pretest for control group, there were 30 or $93.8 \%$ students did not give correct response at all to the list of words. May be because, the students did not learn the word transciption at secondary schools.

Table 6. Frequency and percentage of students' answers in pretest for experimental group

\section{Experiment}

\begin{tabular}{cccccc}
\hline Students' Answers & $\begin{array}{c}\text { Frequen } \\
\text { cy }\end{array}$ & Percent & $\begin{array}{c}\text { Valid } \\
\text { Percent }\end{array}$ & Cumulative Percent \\
\hline \multirow{4}{*}{ Valid } & .00 & 30 & 93.8 & 93.8 & 93.8 \\
& 3.00 & 1 & 3.1 & 3.1 & 96.9 \\
& 4.00 & 1 & 3.1 & 3.1 & 100.0 \\
& Total & 32 & 100.0 & 100.0 & \\
\hline
\end{tabular}

Table 6 reveals the frequency and percentage of students' answers in the pretest for experimental group in the study. From the table, we can see that there were 30 students or $93.8 \%$ did not respond the list of words correctly. There was 1 or $3.1 \%$ of the students gave three correct answers and there was 1 or $3.1 \%$ of them gave four correct answers to the list of words showing English affricate consonants. 
INTERNATIONAL JOURNAL OF ACADEMIC RESEARCH IN PROGRESSIVE EDUCATION AND DEVELOPMENT

Vol. 7, No. 3, July 2018, E-ISSN: 2226-6348 @ 2018 HRMARS

Table 7. Frequency and percentage of students' answers in posttest for control group

Control

\begin{tabular}{cccccc}
\hline Students' Answers & Frequency & Percent & $\begin{array}{c}\text { Valid } \\
\text { Percent }\end{array}$ & Cumulative Percent \\
\hline \multirow{4}{*}{ Valid } & .00 & 23 & 71.9 & 71.9 & 71.9 \\
& 1.00 & 2 & 6.3 & 6.3 & 78.1 \\
& 2.00 & 3 & 9.4 & 9.4 & 87.5 \\
& 3.00 & 3 & 9.4 & 9.4 & 96.9 \\
& 4.00 & 1 & 3.1 & 3.1 & 100.0 \\
\hline
\end{tabular}

Table 7 shows the frequency and percentage of students' answers in the posttest for control group. It is clearly stated in the table that there were 23 or $71.9 \%$ students did not respond the list of words correctly. This means that $71.9 \%$ of the subjects could not identify the correct transcription of the English affricate consonants [t]] and [dz]. There were 3 or $9.4 \%$ gave 2 correct and 3 correct transcription respectively. There were 2 or $6.3 \%$ students gave 1 correct transcription and there was 1 or $3.1 \%$ student gave 4 correct transcription towards the list of words containing English affricate consonants [t]] and [dz].

Table 8. The frequency and percentage of students' answers in posttest for experimental group

\begin{tabular}{cccccc}
\hline Students' Answers & Frequency & Percent & Valid Percent & $\begin{array}{c}\text { Cumulative } \\
\text { Percent }\end{array}$ \\
\hline \multirow{4}{*}{ Valid } & .00 & 16 & 50.0 & 50.0 & 50.0 \\
& 1.00 & 5 & 15.6 & 15.6 & 65.6 \\
& 2.00 & 2 & 6.3 & 6.3 & 71.9 \\
& 3.00 & 6 & 18.8 & 18.8 & 90.6 \\
& 4.00 & 3 & 9.4 & 9.4 & 100.0 \\
\hline
\end{tabular}


INTERNATIONAL JOURNAL OF ACADEMIC RESEARCH IN PROGRESSIVE EDUCATION AND DEVELOPMENT

Vol. 7, No. 3, July 2018, E-ISSN: 2226-6348 @ 2018 HRMARS

Table 8 illustrates the frequency and percentage of students' answers in posttest for experimental group. In this table, we can see that there were some changes or improvement in the students' transciption towards lisf of words containing English affricate consonants $[\mathrm{t}]$ ] and [dz].

As revealed in table 6 that there were 30 or $93.8 \%$ of students who gave inccorrect answers deacresed to 16 or $50 \%$ (table 8). This means that there were 16 or $50 \%$ students could respond the list of words containing English affricate consonants correctly. There were 3 or $9.4 \%$ students gave 4 correct transcription, 6 or $18.8 \%$ students gave 3 correct transcription, 2 of them or $6.3 \%$ gave 2 correct transcription, and 4 of them or $15.6 \%$ gave 1 correnct response.

Table 9. The mean and standard deviation of control and experimental group

\section{Descriptive Statistics}

\begin{tabular}{|c|c|c|c|c|c|}
\hline Group & $\mathrm{N}$ & Minimum & Maximum & Mean & Std. Deviation \\
\hline Control & 32 & .00 & 4.00 & .6562 & 1.18074 \\
\hline Experiment & 32 & .00 & 4.00 & 1.2188 & 1.47527 \\
\hline $\begin{array}{l}\text { Valid N } \\
\text { (listwise) }\end{array}$ & 32 & & & & \\
\hline
\end{tabular}

Tabel 9 reveals that the mean score of control group in posttest was 0.6562 with standard deviation was 1.1807 and the mean score of experimental group in posttest was 1.2188 with standard deviation was 1.4752 .

From the descriptive and infrential statistics, we can see that there was significant improvement of students' affricate consonant acquisition after giving formal instruction in the classroom setting. The mean scores of the pretest and posttest of both experimental and control group are shown in chart 1, 2, 3 and 3 and the significance improvement is revealed in table 10. 
INTERNATIONAL JOURNAL OF ACADEMIC RESEARCH IN PROGRESSIVE EDUCATION AND DEVELOPMENT

Vol. 7, No. 3, July 2018, E-ISSN: 2226-6348 @ 2018 HRMARS
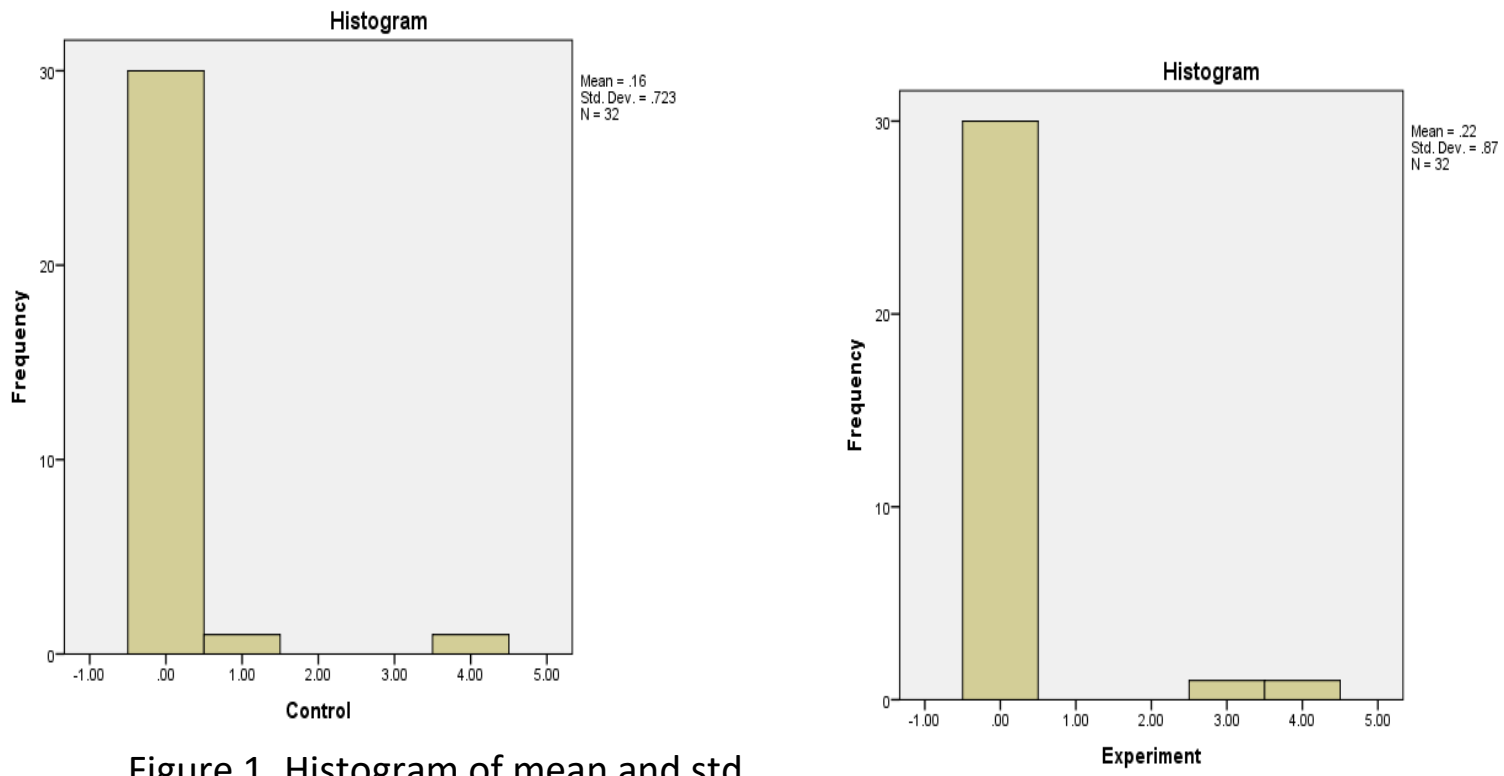

Figure 1. Histogram of mean and std. dev. of control group in pretest

Figure 2. Histogram of mean and std. dev. of experimental group in pretest

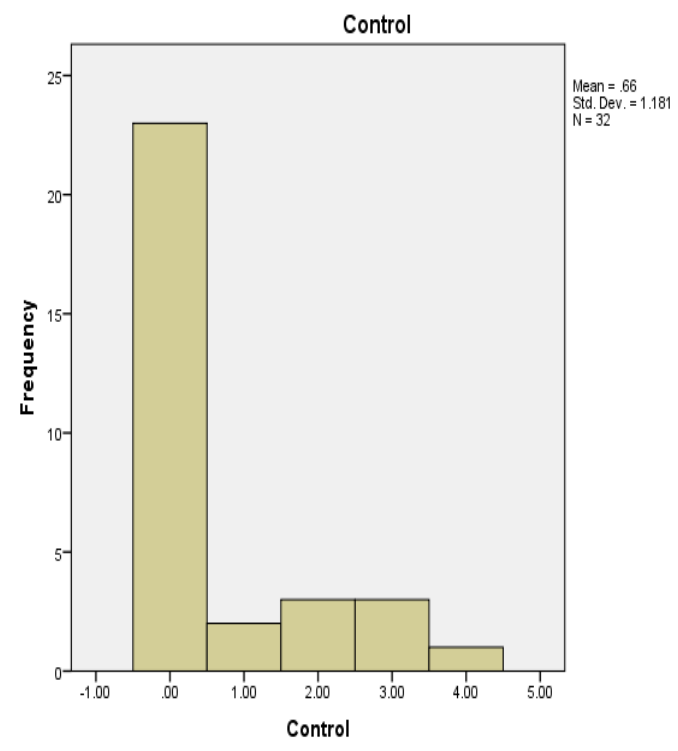

Figure 3. Histogram of mean and std. dev. of control group in posttest

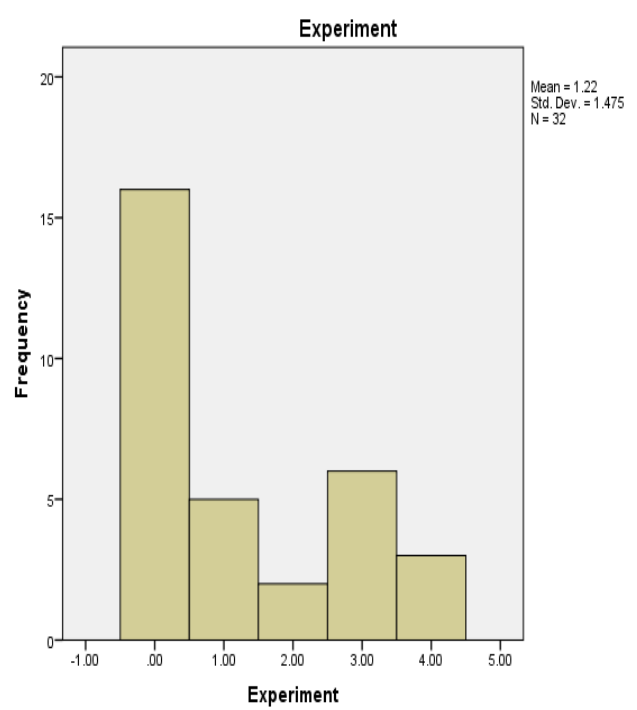

Figure 4. Histogram of mean and std. dev. of experimental group in posttest 
INTERNATIONAL JOURNAL OF ACADEMIC RESEARCH IN PROGRESSIVE EDUCATION AND DEVELOPMENT

Vol. 7, No. 3, July 2018, E-ISSN: 2226-6348 @ 2018 HRMARS

Table 10. The difference of mean score between posttest of experimental and control group

\begin{tabular}{ccccc}
\hline Consonant & \multicolumn{2}{c}{ Mean Score } & Difference & P. Value \\
\cline { 2 - 3 } Acquisition & Experimental & Control & & \\
\hline $\begin{array}{c}\text { Affricate } \\
\text { Consonants }\end{array}$ & 1.2188 & 0.6562 & & 0.5626 \\
\hline
\end{tabular}

Table 10 shows that the probability value was 0.000 is smaller than 0.05 at the level of significance $(0.000<0.05)$. This means that there is a significant difference between control group and experimental group in posttest. This reveals that the acquisition of English affricate consonants of the students of experimental group is significantly higher than the control group after treatment.

\section{Conclusions and Suggestions}

There are two main conclusions of this study. The first one is that the Indonesian learners of English met difficulties in transcribing English affricate consonants [ $t]$ ] and $\left[\mathrm{d}_{3}\right]$ in pretest, either for control group or experimental group. The second main finding as the primary concern of this study is that the formal instruction improved students' acquisition of English affricate consonants $[t]$ and [dz], where the subjects' answers toward the list of words significantly improved in posttest.

The educational implication of the study is that the pronunciation practice by employing formal instruction in the classroom setting with a wide variety of theoretical and practical introduction of affricate consonant sounds is highly recommended to the teachers at tertiary levels and secondary schools in Indonesia. The teachers need to be aware of students' acquisition of English affricate consonants [t]] and [ $\mathrm{d}_{3}$ ] when Indonesian learners of English begin formal instruction. It is important to note that the results of our study reveal that the formal instruction improved students' success in acquiring English affricate consonants.

\section{References}

Bui, T. S. (2016). Pronunciation of consonants $/ \theta /$ and / $/$ by adult Vietnamese EFL learners. Indonesian Journal of Applied Linguistics, Vol. 6 No. 1, pp. 125-134.

Chan, A. Y. W. \& Li, D.C.S. (2000). English and Cantonese phonology in contrast: Explaining Cantonese ESL learners' English pronunciation problems. Language, Culture and Curriculum (pp. 67-85).

Díaz-Campos, M. (2004). Context of learning in the acquisition of Spanish second language phonology. In SSLA, 26, pp. 249-273.

Elliot, A. R. (1995). Foreign language phonology: Field independence, attitude, and the success of formal instruction in Spanish pronunciation. The Modern Language Journal, 79, Issue 4, pp. 530-542.

Elliot, A. R. (1997). On the teaching and acquisition of pronunciation within a communicative approach. In Hispania, Vol. 80. 1, pp. 95-108.

Fromkin, V., \& Rodman, R. (2007). An Introduction to Language. Boston: Thomson Wadsworth. 
INTERNATIONAL JOURNAL OF ACADEMIC RESEARCH IN PROGRESSIVE EDUCATION AND DEVELOPMENT

Vol. 7, No. 3, July 2018, E-ISSN: 2226-6348 @ 2018 HRMARS

Gilakjani, A. P. (2011). A study on the situation of pronunciation instruction in ESL/EFL Classrooms. Journal of studies and education. Vol. 1, No. 1, pp. 1-15. https://dx.doi.org/10.5296/jse.vlil.924.

Gimson, A. C. (1985). An Introduction to the Pronunciation of English. Baltimore: Edward Arnold. González-Bueno, M. (1997). The effects of formal instruction on the acquisition of Spanish stop consonants. Contemporary perspectives on the acquisition of Spanish. In Glass, William R \& Pérez-Leroux, Ana Teresa (Eds.). Somerville: Cascadilla Press.

Hassan, E. M. I. (2014). Pronunciation problems: A case study of English language students at Sudan University of Science and Technology. English Language and Literature Studies, Vo. 4, No. 4 (pp. 31-44). https://dx.doi.org/10.5539/ells.v4n4p31.

Hornby, A. (1987). Oxford advanced learner's dictionary of current English. Oxford. Oxford University Press.

Maeno, Y. (1995). Acquisition of oral narrative skills by foreign language learners of Japanese. MacLauglin, Dawan and McEwen, Susan (eds.), proceedings of the 19th annual Boston University Conference on language development, volume 2.

Mora, J. C., \& Fullana, N. (2007). ICPhs, Saarbrücken, t-10 August 2007.

Roach, Peter. (1987). English phonetics and phonology: A practical course. Cambridge: Cambridge University Press.

Soderberg, C. D. (2008). Indonesian. Journal of the International Phonetic Association, Vol. 38/2, 2008, pp. 209-2013. https://www.cambridge.org/core/services/aop-cambridgecore/content/view/pdf/indonesian.pdf. retrived on 17 November 2016. 